\title{
A Comparative Study of Physico-Chemical Parameter in Glacial Melt Water, Ponkar Glacier, Nepal
}

\author{
Sandeep Shrestha ${ }^{1 *}$, Rajendra Bhandari ${ }^{1}$, Ashish Bashyal ${ }^{2}$, Nischal Shrestha ${ }^{2}$ \\ ${ }^{1}$ Department of Environmental Science and Engineering, Kathmandu University, Dhulikhel, Bagmati, Nepal \\ ${ }^{2}$ Biodiversity Conservancy Nepal, Butwal, Nepal \\ Email: *sandeep@ku.edu.np
}

How to cite this paper: Shrestha, S., Bhandari, R., Bashyal, A. and Shrestha, N. (2021) A Comparative Study of PhysicoChemical Parameter in Glacial Melt Water, Ponkar Glacier, Nepal. Open Access Library Journal, 8: e7160.

https://doi.org/10.4236/oalib.1107160

Received: January 19, 2021

Accepted: February 21, 2021

Published: February 24, 2021

Copyright $\odot 2021$ by author(s) and Open Access Library Inc.

This work is licensed under the Creative Commons Attribution International License (CC BY 4.0).

http://creativecommons.org/licenses/by/4.0/

(c) (i) Open Access

\begin{abstract}
We conducted a detailed study in comparing physico-chemical parameters of glacier melt water between two years $(2016 \& 2019)$ in upstream sites with an elevation ranging from $4100 \mathrm{~m}$ to $3550 \mathrm{~m}$ above sea level of Ponkar glacier, Manang district, Nepal. We conducted onsite testing of physical parameter like $\mathrm{pH}$, electrical conductivity, total dissolved solids, turbidity by using multiprobes and chemical parameters like anions, cations, total silica and heavy metals were analyzed following standard methods from APHA, AWWA, WEF (2012). The mean concentration of total silica was found to be higher in upstream sites than downstream. The elemental ratio $\mathrm{Ca} / \mathrm{Si}$ was found to be higher in glacial melt water with low elemental values for $\mathrm{K} / \mathrm{Na}, \mathrm{Na} / \mathrm{Cl}$ and $\mathrm{K} / \mathrm{Cl}$. The average concentration of parameters like electrical conductivity, turbidity, total hardness in glacier melt water was recorded to be higher in year 2019 than 2016. The mean concentration of anions and heavy metal was recorded to be higher in year 2016 than 2019 . This study has provided a baseline information in comparing physico-chemical parameters in glacial melt water of Ponkar glacier and will be helpful in mitigating adverse impacts of climate change in Nepal's glacier.
\end{abstract}

\section{Subject Areas}

Environmental Sciences, Natural Geography, Oceanology

\section{Keywords}

Glacier, Physico-Chemical Parameters, Concentration, Ions, Upstream, Downstream 


\section{Introduction}

Glaciers function over a number of temporal and spatial scales as water reservoirs of fresh water (Jansson et al. 2003) [1] and provide downstream consumers with water during times of low precipitation (Kaser et al. 2010 [2]; Viviroli et al. $2011[3])$. The Hindu Kush Himalaya covers eight countries including Afghanistan, Bangladesh, Bhutan, China, India, Nepal, Myanmar and Pakistan (Bajracharya et al. 2011) [4] and is probably the most significant "water tower" in the world, being the source of ten of the largest rivers in Asia and the largest amount of ice and snow outside the Arctic and Antarctica and thus is popularly "known as the third pole". The Himalayan range extends for approximately 2400 $\mathrm{km}$ within the $3500 \mathrm{~km}$ length of the Hindu Kush-Himalayan ranges, and has about 33,000 sq.km of the estimated 110,000 sq.km of the glaciated area. The Himalayas of Nepal occupy $800 \mathrm{~km}$ of the central part of the Himalayan range (ICIMOD, 2011) [5]. These Himalayas can be used as climate change proxies with an approximate rise of $0.04^{\circ} \mathrm{C}-0.09^{\circ} \mathrm{C} /$ year as they are highly vulnerable to climate change and continuously display the signs of diminishing and retreating that have been rising in recent decades resulting into the rapid melting of glaciers thereby reducing the glacier area by fragmenting the glacier with increase in glacier number (Bajracharya et al. 2008) [6]. As chemical weathering rates are strong and anthropogenic consequences are mostly so small, glaciered areas are an excellent place to study water-rock interaction (Brown, 2002) [7]. The chemical composition of the underlying rocks in the glacier depends on precipitation and chemical composition (Vasilchuk, 2009) [8].

One of Nepal's dominant water supplies, which the country relies on for drinking water, irrigation and hydropower, is melting water from mountain glaciers in the Himalayas. The main water supplies in Nepal derive from glaciers in the Himalayas that melt rapidly due to continued increase in earth temperature causing hydrological changes in the headwater of the river (Bhatt et al. 2016) [9]. However, as a result of global climate change, accelerated glacial retreats may have major influence on hydrological regimes, resulting in a decline in water resources, quality and quantity (IPCC, 2007 [10]; Moore, 2009 [11]).

The complex weathering dynamics functioning in the glaciated river catchments is yet to understand, so the research on melt water hydrochemistry of glaciers is critical for water supply management in the Himalaya, and also for the study of the impacts of global climate change on these glaciers. In contrast, the rising demand for freshwater for drinking, agricultural and hydropower purposes as well as the ecological climate in downstream stretches has made the hydro-chemical analysis of Himalayan glaciers extremely imperative (Singh et al. 2012) [12]. Mountain melt water hydrochemistry is strongly influenced by the chemical structure of atmospheric deposition and by the features of the atmosphere (Gibbs, 1970 [13]; Nijampurkar et al. 1993 [14]). To determine the consistency of melt water and also to classify the origins of dissolved ions in the glacier environment, hydro-geochemical characterization of glacier melt water with re- 
spect to dissolved ion components is very useful. It is important to provide baseline knowledge on the physico-chemical characteristics of melting waters from the glacier in order to fill the gaps that exist in the hydrochemistry study of glaciers in Nepal.

\section{Materials and Methods}

\section{Study Area}

We carried our study in Ponkar glacier, a debris covered glacier with thickness of $134.05 \mathrm{~m}$, having area of $28.509 \mathrm{~km}^{2}$ and located in an elevation of $5679 \mathrm{~m}$ above sea level (ICIMOD, 2010) [15]. The glacier is located in Bhimthang Valley, Manang District of Gandaki Province in Nepal (Figure 1). It lies between $28^{\circ} 35^{\prime} 00^{\prime \prime}$ to $28^{\circ} 45^{\prime} 00^{\prime \prime}$ latitude and $84^{\circ} 25^{\prime} 00^{\prime \prime}$ to $84^{\circ} 30^{\prime} 00^{\prime \prime}$ longitude.

\section{Sampling and Analysis}

A total of 16 water sampling stations were established in Ponkar glacier (Figure 1) with an altitude of PG1-4100 m to PG16-1930 m. The stations PG1 through PG16 correspond to decreasing altitudes $4100 \mathrm{~m}$ to $1930 \mathrm{~m}$ as already described in our previously published paper in Thapa et al. 2019 [16]. We have considered water sampling sites from PG1-4100 m to PG7-3650 m as upstream sites (Figure 1) and PG8-3583 m to PG16-1930 m as downstream sites (Figure 1). After the end of glacier terminus, the glacier melt water mix with river, which we have considered those sites as downstream sites where water finally mix into big Marsyandhi river basin.

The water samples were collected in Pre monsoon season (2017 and 2018), then stored in freezer and analyzed within 2 weeks in Department of Environmental Engineering and Science Laboratory, Kathmandu University, Nepal and the laboratory of Environment and Public Health Organization (ENPHO), Nepal. Physical water quality parameters for each of the sample stations were measured using calibrated standardized probes: electrical Conductivity, $\mathrm{pH}$ and total dissolved solids (TDS) were measured using Multiprobe HI 98194 while turbidity was measured by using turbidity meter: Model no HI 98713 and both instruments were calibrated before taking data. The cations, anions, total silica and heavy metals of glacier melt water were analyzed using following method from APHA, AWWA, WEF (2012) [17]: Calcium-2500 Ca B; Magnesium-3500 Mg B; Sodium-3500 Na B; Potassium-3500 K B; Total silica-4500 $\mathrm{SiO}_{2} \mathrm{C}$; Iron-3111 B; Zinc-3111 B; Manganese-3111 B; Alumunium-3500 Al B.; $\mathrm{HCO}_{3}^{-}$-Titrimetric; Chloride-Titrimetric; Nitrate and Total Phosphorus-Ultraviolet Spectrophotometric Screening method. A comparative study of different physico-chemical parameters like $\mathrm{pH}$, electrical conductivity, total solids, total dissolved solids, total hardness, turbidity, anions and heavy metals in upstream sites of Ponkar glacier was done between the data we collected (published in our previous paper Thapa et al. 2019 [16]) and data collected by Shrestha, 2016 [18] (B.Sc thesis 2016, unpublished data) at the same sample stations. This comparison will help us predicting the effect of climate change in the physico-chemical parameters of 


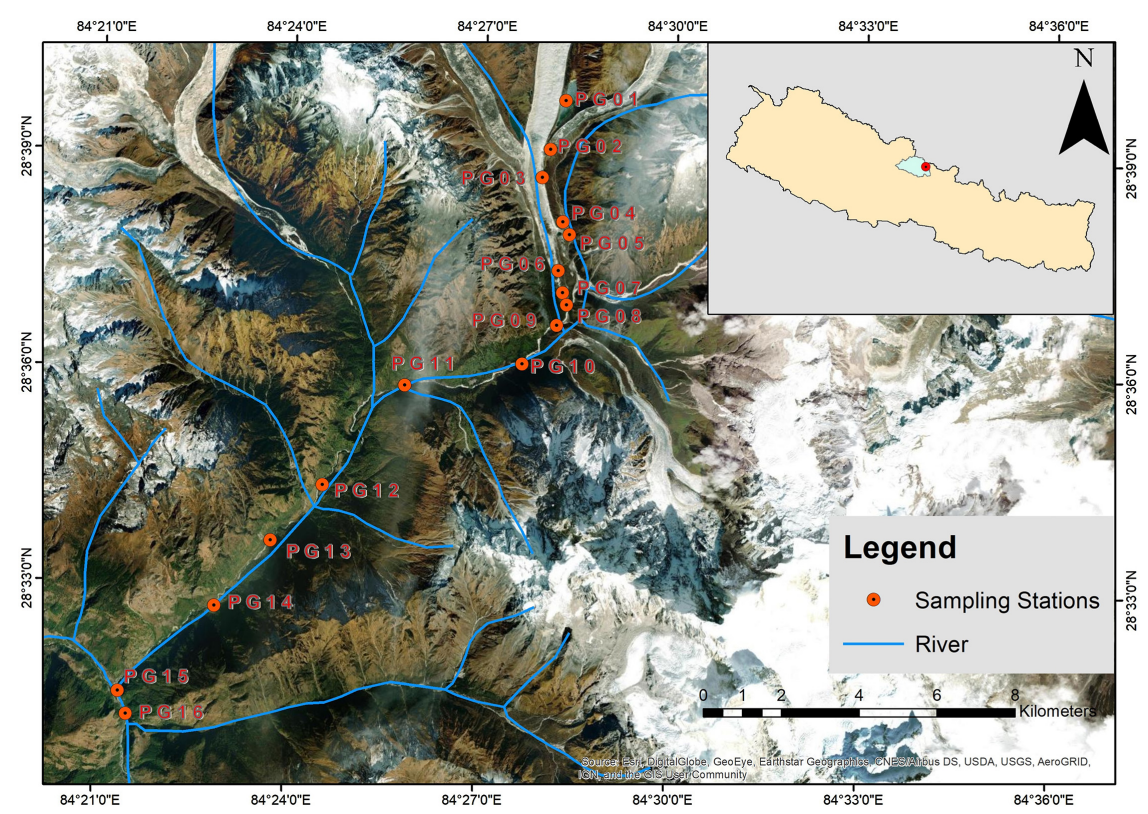

Figure 1. Map of study area showing sampling points.

glacier melt water of Ponkar glacier over years. Further we have analyzed our previously published data to study the dependence of physical parameters at different altitudes in Ponkar glacier. We performed our data analysis using simple statistical parameters like mean, standard deviation and t-test to check the statistical significance of the data obtained in Microsoft excel.

\section{Results and Discussion}

We have already published the data of physico-chemical analysis of glacier melt water of Ponkar glacier, Manang district, Nepal in our paper Thapa et al. 2019 [16]. Further, we conducted analysis of our data that would help boarder understanding of glacier melt water chemistry of Ponkar glacier. We calculated Charge balance errors by the formula $\left(\mathrm{TZ}^{+}-\mathrm{TZ}^{-} / \mathrm{TZ}^{+}+\mathrm{TZ}^{-} \times 100\right)$ (Freeza and Cherry, 1979) [19] and the result were found to be less than $10 \%$.

The TDS/EC ratio was 0.430 , demonstrating the efficiency and consistency of the analytical performance. Taking altitude as dependent variable, different physico-chemical parameters as $\mathrm{pH}$, electrical conductivity, turbidity, total solids, total dissolved solids were plotted as independent variables for Thapa et al 2019 [16]. The results showed that $\mathrm{pH}$ is almost same throughout the upstream and downstream of the glacier (Figure 2(a)). Thus we see that average $\mathrm{pH}$ is neutral with respect to melting water of Ponkar glacier. In contrary total hardness (TH) is somewhat seen to increase with altitude. But, the plot of hardness versus altitude was not a perfect linear fit $\left(R^{2}<0.9\right)$ (Figure $\left.2(\mathrm{~b})\right)$ indicating that even if the altitude of the glacier affects total hardness of water but $R^{2}=0.5164$. Further we did not see any linear dependence of other parameters as turbidity, total solids, total dissolved solids and electrical conductivity with respect to altitude in the Ponkar glacier. 


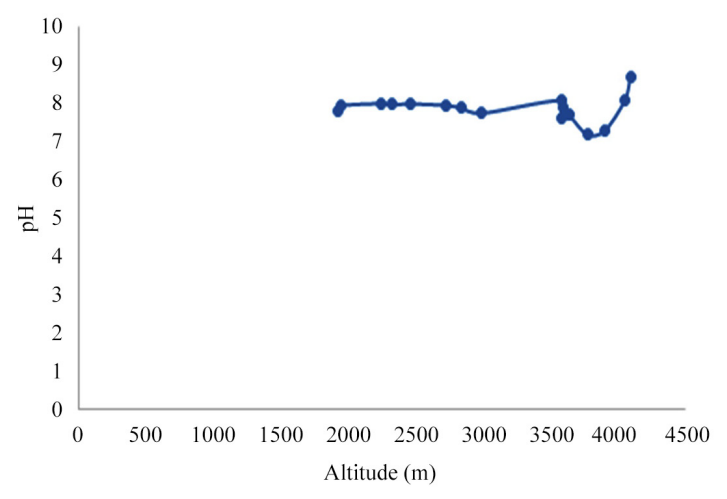

(a)

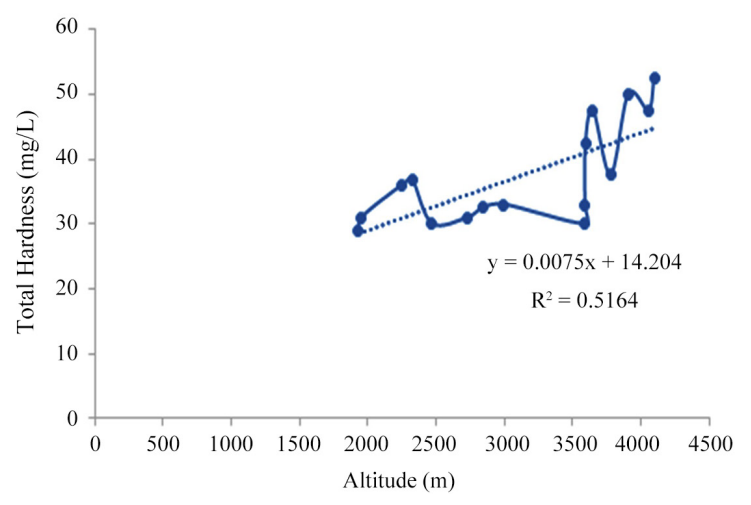

(b)

Figure 2. (a) Relationship between $\mathrm{pH}$ and altitude; (b) Relationship between $\mathrm{TH}$ and altitude.

The cumulative silica present in the water consists of "Reactive Silica" and "Unreactive Silica." We have analyzed total silica concentration of glacier melt water in downstream sites in altitude $3583 \mathrm{~m}$ (PG 8) to1930 m (PG 16) and recorded mean concentration to be $6.33 \pm 1.13 \mathrm{mg} / \mathrm{L}$ (Figure 3 ). The highest concentration of total silica was found to be $8.78 \mathrm{mg} / \mathrm{L}$ in downstream sites and was recorded in $2323 \mathrm{~m}$ (PG 13). Shrestha, 2016 [18] recorded mean concentration of total silica to be $1.12 \pm 0.74 \mathrm{mg} / \mathrm{L}$ in upstream sites of Ponkar glacier and recorded highest concentration in $4100 \mathrm{~m}$ (PG 1). The total silica is considerably higher in melt water of Ponkar glacier than other glaciers due to higher deposition from granite rock fragments composed of moraine sediments (Shrestha, 2016) [18].

We measured the concentration of cations, anions and heavy metals in glacial melt water of Ponkar glacier, as published in our previous paper Thapa et al. 2019 [16]. Further, based on these data from Thapa et al. 2019 [16], we have calculated the elemental ratios of melt water of Ponkar glacier as seen in Table 1. The overall $\mathrm{Ca} / \mathrm{Si}$ ratio is believed to be higher in glacial waters due to preferential carbonate weathering and sluggish silicate weathering (Tranter, 1993) [20]. The hydrochemistry of the glacier melt water is likely to be determined by combining two components of carbonate and silicate dissolution, and the relative importance of these two sources can be explained by the cationic abundance and its ratios (Singh et al. 2005) [21]. The elemental ratio of $\mathrm{K} / \mathrm{Na}$ was found to be 0.0053 and in general, average K/Na ratio is slightly higher in glacial runoff than the non-glacial runoff owing to the preferential weathering of K-mica minerals resulting in high $\mathrm{K}$ concentrations (Anderson, 1997) [22]. The average ratio of $\mathrm{Na} / \mathrm{Cl}$ and $\mathrm{K} / \mathrm{Cl}$ was similar to that of seawater $(\mathrm{Na} / \mathrm{Cl}=1.0$ and $\mathrm{K} / \mathrm{Cl}=0.2)$. These ratios suggested a significant contribution from atmospheric precipitation to the detected dissolved ions in the glacier melt water. However, the release of dissolved ions to the glacier streams is governed by the rock-water interaction, bed rock mineralogy, weathering reactions, composition of atmospheric deposition and rate of water flow in the glacier catchment (Singh and Hasnain, 1998) [23]. 


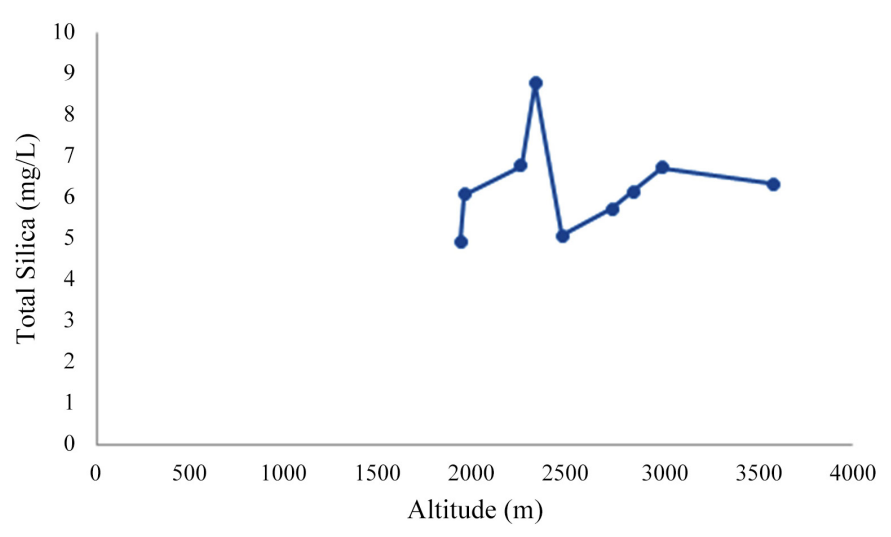

Figure 3. Concentration of Silica in different altitudes of downstream sites.

Table 1. Elemental Ratio in melt water of Ponkar glacier.

\begin{tabular}{ccccc}
\hline & Minimum & Maximum & Mean & Std. Deviation \\
\hline $\mathrm{Ca} / \mathrm{Si}$ & 1.187 & 4.555 & 3.065 & 0.829 \\
$\mathrm{~K} / \mathrm{Na}$ & 0.053 & 0.649 & 0.354 & 0.173 \\
$\mathrm{Na} / \mathrm{Cl}$ & 0.197 & 0.731 & 0.349 & 0.153 \\
$\mathrm{~K} / \mathrm{Cl}$ & 0.012 & 0.244 & 0.116 & 0.057 \\
\hline
\end{tabular}

Shrestha, 2016 [18] conducted study in physico-chemical parameters of glacier melt water of Ponkar glacier in upstream sites (PG1-PG7) and Thapa et al. 2019 [16] also conducted study in physico-chemical parameters (analyzed cations which was not done by Shrestha, 2016) from the same water sample stations of upstream sites. The differences in concentrations of physico-chemical glacier melt water between the two sampling years (Shrestha, 2016 [18] and Thapa et al. 2019 [16]) in the Ponkar glacier recorded similar concentration for $\mathrm{pH}$, total solids and total dissolved solids however, Thapa et al. 2019 [16] recorded higher concentration of electrical conductivity, turbidity and total hardness in glacier melt water compared to Shrestha, 2016 [18] (Figure 4). Statistical analysis shows that the electrical conductivity ( $\mathrm{p}$ value $=0.034$ ) and turbidity ( $\mathrm{p}$ value $=0.04$ ) have increased significantly in 2 years using one tail $t$ test. However there is no statistical significance in total hardness ( $\mathrm{p}$ value $=0.059$ ). The significant increase ( $\mathrm{p}$ value $<0.05$ ) in these physical parameters over the course of time can be correlated with the impacts of climate change. Also no statistical significance in $\mathrm{pH}$ value of this water glacier indicates that $\mathrm{pH}$ of water is not affected by the increase in chemical weathering of glacial rocks over years.

We found differences in the concentration of anions between two years in Ponkar glacier (Figure 5). Shrestha, 2016 [18] recorded mean concentration of $\mathrm{HCO}_{3}^{-}$with a value of $194.2 \mathrm{mg} / \mathrm{L}$ while Thapa et al. 2019 [16] recorded mean concentration of $\mathrm{HCO}_{3}^{-}$to be $42.09 \mathrm{mg} / \mathrm{l}$. Similarly, Shrestha, 2016 reported $55.70 \mathrm{mg} / \mathrm{L}$ of chloride, but in comparison to that, Thapa et al. 2019 [16] recorded $9.59 \mathrm{mg} / \mathrm{L}$ of chloride. Shrestha, 2016 [18] found the mean concentration of sulphate $11.53 \mathrm{mg} / \mathrm{L}$ but mean concentration of $6.3 \mathrm{mg} / \mathrm{L}$ of sulphate was rec- 
orded in upstream sites by Thapa et al. 2019 [16]. Nitrate was not detected in seven sampling stations of upstream sites carried by Thapa et al. 2019 [16]. However, the mean concentration of $1.0 \mathrm{mg} / \mathrm{L}$ of nitrate was recorded by Shrestha, 2016. The concentration of anions is in the order of $\mathrm{HCO}_{3}^{-}>\mathrm{Cl}^{-}>$ $\mathrm{SO}_{4}^{2-}>\mathrm{NO}_{3}^{-}>\mathrm{TP}_{-} \mathrm{PO}_{4}^{3-}$ for both years of study (Shrestha, 2016 [18]; Thapa et al. 2019 [16]). The overall comparative analysis of anions in the upstream sites of Ponkar glacier indicates that the contact period of melting water with sediment below the glacier and the weathering rate of Ponkar glacier is higher in the study performed by Shrestha, 2016 [18] than that of Thapa et al. 2019 [16]. We did not compare the concentration of anions as Shrestha, 2016 [18] did not measure anions for the upstream sites.

Similarly, comparing the heavy metals concentrations in glacier melt water for upstream sites between two successive years, Shrestha, 2016 [18] recorded high amounts of aluminum and iron compared to Thapa et al. 2019 [16] (Figure 6). The mean concentration of manganese was found equal in both years (Shrestha, 2016 [18] and Thapa et al. 2019 [16]). But mean concentration of zinc recorded was higher in Thapa et al. 2019 [16] than recorded by Shrestha, 2016 [18]. Studies carried by Tuladhar et al. 2015 [24] in Lirung glacier Nepal, recorded increase in concentration of major cations, anions and heavy metals in glacier melt water compared to previous year. However, our comparative study recorded high concentration of anions and heavy metals higher for Shrestha, 2016 [18] than Thapa et al. 2019 [16]. There is decrease in the concentration of total Phosphorus and nitrate concentration as recorded by Thapa et al. 2019 [16] than Shrestha, 2016 [18]. Anthropogenic impacts would increase in the concentration of total Phosphorus and Nitrate in glacier melt water (Bhandari et al. 2015 [25]; Tuladhar et al. 2015 [24]). However, it shows that there is less influence of anthropogenic activities in upstream sites of Ponkar glacier. Recent, climate change impacts have increased temperature of Himalayas in Nepal by $0.06^{\circ} \mathrm{C}$ resulting in increase in chemical weathering and recording higher concentration of anions, cations and heavy metals in glacier melt water in recent years (Chalise et al. 2006 [26]; Tuladhar et al. 2015 [24]).

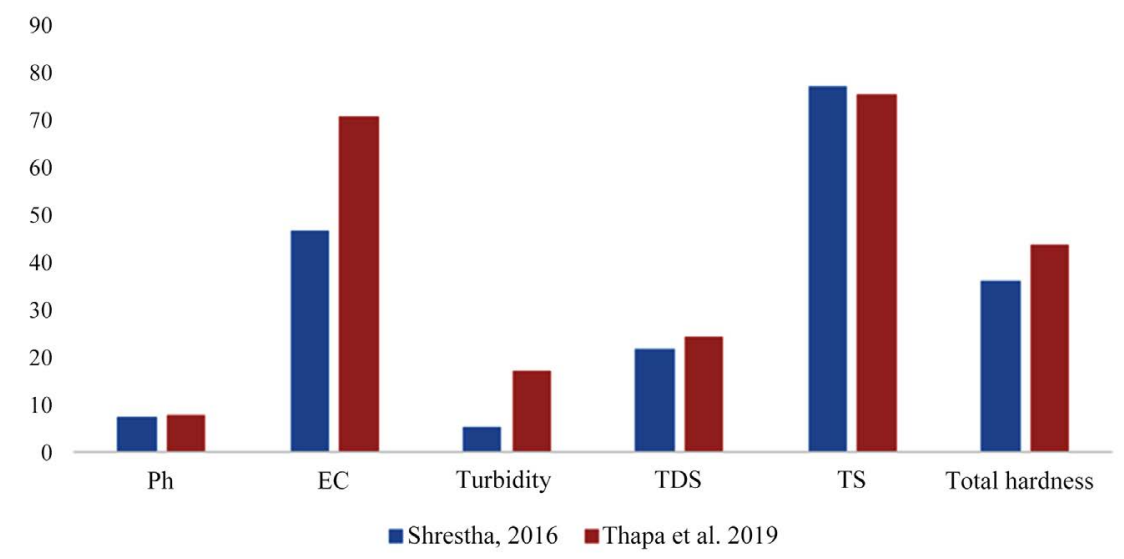

Figure 4. Comparative concentration of physical characteristics of melt water of Ponkar Glacier. 


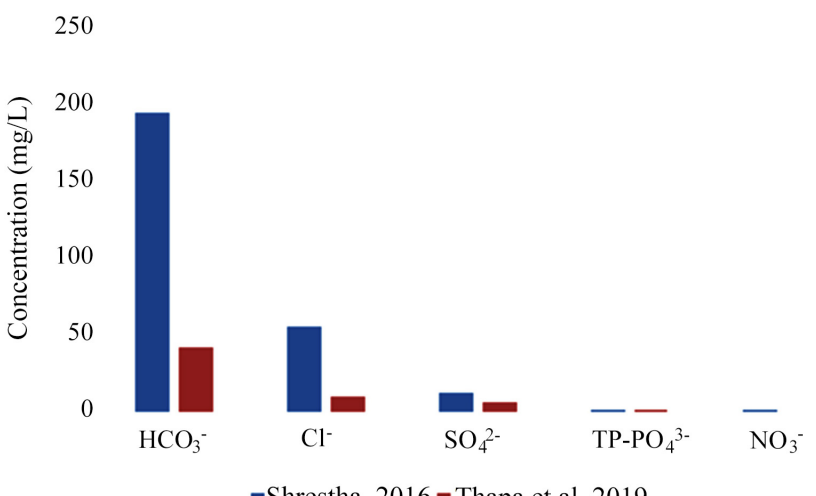

Figure 5. Comparative concentration of major anions in meltwater of Ponkar Glacier.

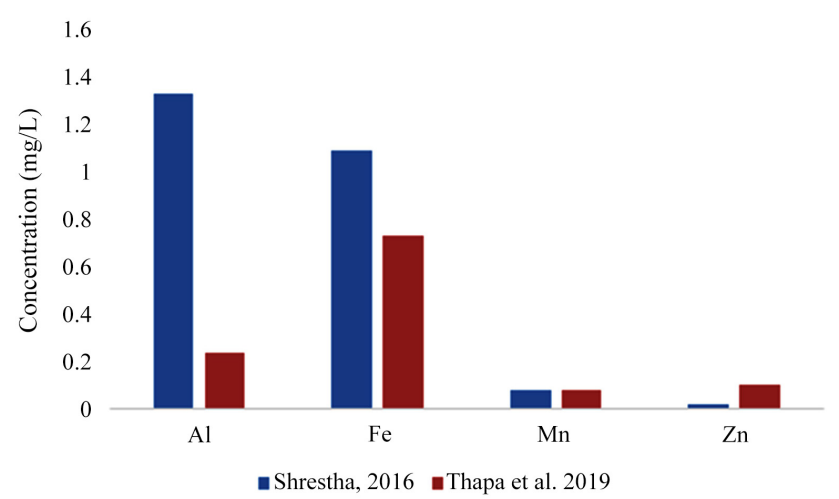

Figure 6. Comparative concentration of heavy metals in melt water of Ponkar Glacier between two years.

\section{Conclusion}

This study has compared physico-chemical parameters data from two different years in melt water draining from the Ponkar Glacier, Manang, Nepal. The comparative study of the Ponkar glacier in relation to the previous year reveals that the mean concentration physical parameters like electrical conductivity, turbidity and total Hardness were higher in 2019 than 2016. In both the studies, the concentration of anions is in the order of $\mathrm{HCO}_{3}^{-}>\mathrm{Cl}^{-}>\mathrm{SO}_{4}^{2-}>\mathrm{NO}_{3}^{-}>$ TP-PO ${ }_{4}^{3-}$. The elemental ratios $(\mathrm{Ca} / \mathrm{Si}$ and $\mathrm{K} / \mathrm{Na})$ were typical of glacial melt water and the low $\mathrm{Na} / \mathrm{Cl}$ and $\mathrm{K} / \mathrm{Cl}$ ratios indicated major contribution from atmospheric precipitation to the observed dissolved ions of melt waters. It is expected that further studies will be conducted to mitigate the rising global temperatures, which would eventually lead to intensify chemical weathering and increase concentrations of anions, cations and heavy metals in the melting water of the glacier in coming years.

\section{Acknowledgements}

The research work was carried by funding received under Faculty research grant (2073-74) from University Grant Commission, Nepal. 


\section{Conflicts of Interest}

The authors declare no conflicts of interest regarding the publication of this paper.

\section{References}

[1] Jansson, P., Hock, R. and Schneider, T. (2003) The Concept of Glacier Storage: A Review. Journal of Hydrology, 282, 116-129. https://doi.org/10.1016/S0022-1694(03)00258-0

[2] Kaser, G., Groshauser, M. and Marzeion, B. (2010) Contribution Potential of Glaciers to Water Availability Indifferent Climate Regimes. Proceedings of the National Academy of Sciences of the United States of America, 107, 20223-20227. https://doi.org/10.1073/pnas.1008162107

[3] Viviroli, D., Archer, D.R. and Buytaert, W. (2011) Climate Change and Mountain Water Resources: Overview and Recommendations for Research, Management and Policy. Hydrology and Earth System Sciences, 15, 471-504. https://doi.org/10.5194/hess-15-471-2011

[4] Bajracharya, S.R. and Shrestha, B. (2011) The Status of Glaciers in the Hindu Kush-Himalayan Region. International Centre for Integrated Mountain Development, Lalitpur.

[5] International Centre for Integrated Mountain Development (2011) Report on the Impact of Climate Change on Water Resources and Livelihoods in the Himalayas. International Centre for Integrated Mountain Development, Lalitpur.

[6] Bajracharya, S.R., Mool, P.K. and Shrestha, B.R. (2008) Global Climate Change and Melting of Himalayan Glaciers. In: Shastri Ranade, P., Ed., Melting Glaciers and Rising Sea Levels. Impacts and Implications, The Icfai's University Press, Dehradun, 28-46.

[7] Brown, G.H. (2002) Glacier Meltwater Hydrochemistry. Applied Geochemistry, 17, 855-883. https://doi.org/10.1016/S0883-2927(01)00123-8

[8] Vasil'chuk, Yu.K. (2009) Chemical Properties of Glacial and Ground Ice. In: Khublaryan, M.G., Ed., Types and Properties of Water, Vol. II, Eolss Publishers, Paris, 265.

[9] Bhatt, M.P., Takeuchi, N. and Acevedo, M.F. (2016) Chemistry of Supraglacial Ponds in the Debris-Covered Area of Lirung Glacier in Central Nepal Himalayas. Aquatic Geochemistry, 22, 35-64. https://doi.org/10.1007/s10498-015-9276-9

[10] Intergovernmental Panel on Climate Change (2007) IPCC Fourth Assessment Report. Climate Change, Working Group II: Impacts, Adaptation and Vulnerability. Intergovernmental Panel on Climate Change, Geneva.

[11] Moore, R.D. (2009) Glacier Change in Western North America: Influences on Hydrology, Geomorphic Hazards and Water Quality. Hydrological Process, 23, 42-61. https://doi.org/10.1002/hyp.7162

[12] Singh, V.B., Ramanathan, A.L., Pottakkal, J.G., Sharma, P., Linda, A., Azam, M.F. and Chatterjee, C. (2012) Chemical Characterization of Meltwater Draining from Gangotri Glacier, Garhwal Himalaya, India. Journal of Earth System Science, 121, 625-636. https://doi.org/10.1007/s12040-012-0177-7

[13] Gibbs, R.J. (1970) Mechanisms Controlling World Water Chemistry. Science, 170, 1088-1090. https://doi.org/10.1126/science.170.3962.1088

[14] Nijampurkar, V.N., Sarin, M.M. and Rao, D.K. (1993) Chemical Composition of 
Snow and Ice from Chhota Shigri Glacier, Central Himalaya. Journal of Hydrology, 151, 19-34. https://doi.org/10.1016/0022-1694(93)90246-6

[15] Ives, J.D., Shrestha, R.B. and Mool, P.K. (2010) Formation of Glacial Lakes in the Hindu Kush-Himalayas and GLOF Risk Assessment. International Centre for Integrated Mountain Development, Kathmandu.

[16] Thapa, K., Shrestha, S., Sharma, K., Shrestha, N., Bhandari, R., Bashyal, A. and Shrestha, S. (2019) Assessment of Physico-Chemical Parameters of Meltwater of Ponkar Glacier, Manang, Nepal. Hydrology: Current Research, 10, 313.

[17] Apha, A.W., Greenberg, W.I.A., Clesceri, L. and Eaton, A. (2012) Standard Methods for the Examination of Water and Wastewater. American Public Health Association, Washington DC.

[18] Shrestha, R. (2016) Hydro-Chemical Characterization of Glacier Meltwater of Ponkar Glacier, Manang, Nepal. B.Sc. Environmental Science, Kathmandu University, Dhulikhel. (Unpublished)

[19] Freeza, R.A. and Cherry, J.A. (1979) Groundwater. Prentice-Hall Inc., Englewood Cliffs.

[20] Tranter, M., Brown, G.H., Sharp, M.J. and Gurnell, A.M. (1993) A Conceptual Model of Solute Acquisition by Alpine Glacial Meltwaters. Journal of Glaciology, 39, 573-581. https://doi.org/10.3189/S0022143000016464

[21] Singh, P., Haritashya, U.K., Ramasastri, K.S. and Kumar, N. (2005) Diurnal Variations in Discharge and Suspended Sediment Concentration, Including $\mathrm{Ru}$ noff-Delaying Characteristics, of the Gangotri Glacier in the Garhwal Himalayas. Hydrological Processes, 19, 1445-1457. https://doi.org/10.1002/hyp.5583

[22] Anderson, S.P., Drever, J.I. and Humphrey, N.F. (1997) Chemical Weathering in Glacial Environments. Geology, 25, 399-402. https://doi.org/10.1130/0091-7613(1997)025\%3C0399:CWIGE\%3E2.3.CO;2

[23] Singh, A. K. and Hasnain, S. I. (1998) Major Ion Chemistry and Weathering Control in a High Altitude Basin: Alaknanda River, Garhwal Himalaya, India. Hydrological Sciences Journal, 43, 825-843. https://doi.org/10.1080/02626669809492181

[24] Tuladhar, A., Kayastha. R.B., Gurung, S. and Shrestha, A. (2015) Hydro-Chemical Characterization of Glacial Melt Waters Draining from Langtang Valley, Nepal. Journal of Water Resource and Protection, 7, 605-613. http://dx.doi.org/10.4236/jwarp.2015.78049

[25] Bhandari, R., Sharma, S., Merz, J. and Garton, R. (2015) Hydro-Chemistry of Gokyo Valley, Sagarmatha (Everest) National Park, Nepal. Journal of Geoscience and Environment Protection, 3, 74-81. http://dx.doi.org/10.4236/gep.2015.39007

[26] Chalise, S.R., Shrestha, M.L., Bajracharya, O.R. and Shrestha, A.B. (2006) Climate Change Impacts on Glacial Lakes and Glacierized Basins in Nepal and Implications for Water Resources. Proceedings of the 5th FRIEND World Conference, Havana, November 2006, 460-465. 